\title{
\begin{tabular}{|c|c|}
\hline Jurnal Abdimas Saintika & e-ISSN : 2715-4424 \\
p-ISSN :2746-797X \\
\hline
\end{tabular}
}

\section{EDUKASI DAN KAMPANYE KESEHATAN PERILAKU HIDUP BERSIH DAN SEHAT (PHBS) DI ERA PANDEMI COVID-19 BAGI ANAK PANTI ASUHAN}

\author{
Mila Triana Sari ${ }^{1 *}$, Miko Eka Putri ${ }^{2}$, Daryanto $^{3}$, Etriyanti $^{4}$ \\ Stikes Baiturrahim \\ *Email:milatrianasari73@gmail.com
}

\begin{abstract}
ABSTRAK
Corona virus(Covid-19) merupakan penyakit infeksi yang penyebarannya sangat cepat sekarang ini. Anak-anak termasuk ke dalam kelompok usia yang sangat rentan terhadap penularan Covid-19 dari lingkungan sekitarnya, termasuk dalam hal ini adalah anak yatim piatu yang tinggal di panti asuhan. Salah satu upaya untuk meminimalisir penularan Covid-19 pada anak di panti asuhan, perlu dilakukan edukasi untuk mengajarkan bagaimana perilaku hidup bersih dan sehat yang menjadi protokol pegangan Covid-19. Kegiatan pengabdian ini dilakukan di panti asuhan Ummi al Ikhlas, Kelurahan Mayang Mengurai Kota Jambi, pada tanggal 9 Januari 2021 yang dimulai dari jam 08.30 11.30, yang bertujuan meningkatkan pengetahuan dan pemahaman serta kesadaran anak panti asuhan terkait prilaku hidup bersih dan sehat serta perubahan sikap dan perilaku untuk hidup sehat secara mandiri, meliputi cara memakai masker, cara mencuci tangan 6 langkah memakai sabun dan air mengalir, serta etika batuk yang benar. Metode pelaksanaan yang digunakan adalah edukasi, diskusi, tanya jawab serta demonstrasi dan redemonstrasi. Kegiatan ini dihadiri oleh 37 peserta termasuk pengasuh panti asuhan, tim pengabmas Stikes Baiturrahim serta anak-anak panti asuhan Ummi alIkhlas. Hasil kegiatan Pengasuh dan anak anak panti asuhan memiliki sikap yang positif tentang pentingnya PHBS dalam upaya pencegahan penularan covid-19, dan seluruh penghuni panti asuhan Ummi Al- Ikhlas setuju untuk menerapkan PHBS dalam kehidupan sehari hari mereka terutama pada masa pandemi covid-19 ini. Perlu dilakukan kegiatan pendampingan untuk pemantauan pola Hidup Bersih dan Sehat yang dilakukan oleh pengasuh panti atau dari anak asuh yang sudah remaja membimbing adik-adiknya agar dapat konsisten melaksanakan pola hidup bersih dan sehat, sehingga dapat membantu anak-anak panti asuhan untuk dapat menambah wawasan dan keterampilan untuk meningkatkan hidup sehat dan terhindar dari penularan Covid-19.
\end{abstract}

Kata Kunci : Edukasi, Covid-19, Pengetahuan, PHBS, Panti asuhan

\section{ABSTRACT}

Corona virus (Covid-19) is an infectious disease that is spreading very fast now. Children are included in the age group that is very vulnerable to Covid-19 transmission from their surrounding environment, including in this case are orphans living in orphanages. One of the efforts to minimize the transmission of Covid-19 to children in orphanages, education is needed to regulate how to live clean and healthy behavior, which is the protocol for Covid-19. This service activity was carried out at the Ummi al Ikhlas orphanage, Mayang Mengurai Village, Jambi City, on January 9, 2021, starting from 08.30-11.30, which aims to increase the knowledge and understanding and awareness of the orphanage children regarding clean and healthy living habits and changing attitudes. and behaviors to live healthy independently, including how to wear a mask, how to use 6 steps to use soap and running water, and correct cough etiquette. The implementation methods used are education, discussion, question and answer, and redemonstration. This activity was attended by 37 participants including the orphanage caretakers, the Stikes Baiturrahim community service team and the children of the Ummi al-Ikhlas orphanage. The results of the activities of caregivers and orphanage children 


\section{Jurnal Abdimas Saintika}

Volume 3 Nomor $1 \mid$ https://jurnal.syedzasaintika.ac.id

have a positive attitude about the importance of PHBS in efforts to prevent Covid-19 transmission, and all residents of the Ummi Al-Ikhlas orphanage agree to implement PHBS in their daily lives, especially during the Covid-19 pandemic. Assistance activities need to be carried out to implement a Clean and Healthy lifestyle carried out by the orphanage caregivers or adolescent foster children guiding their younger siblings so that they can carry out training in clean and healthy living patterns, so that they can help the orphanage children gain insight and skills. to improve a healthy life and avoid transmission of Covid-19.

Keywords: Education, Covid-19, Knowledge, PHBS, Orphanage

\section{LATAR BELAKANG}

Corona virus merupakan penyakit yang penyebarannya sangat cepat sekarang ini. Corona Virus Disease 2019 atau COVID-19 adalah jenis penyakit baru yang disebabkan oleh infeksi Virus Severe Acute Respiratory Syndrome Coronavirus 2 (SARSCOV-2) atau yang dikenal dengan novel coronavirus (2019-nCoV) (Singhal, 2020). Dari awal kemunculannya di akhir tahun 2019 hingga 20 Mei 2020, penyakit ini telah menginfeksi 4.789.205 orang ( Zukmadini et al, 2020), serta menyebabkan kematian terhadap 318.789 orang di seluruh dunia. (WHO, 2020).

Penyakit ini ditularkan melalui droplet (percikan) pada saat berbicara, batuk, dan bersin dari orang yang terinfeksi virus Corona. Selain itu penyakit ini juga dapat ditularkan melalui kontak fisik (sentuhan atau jabat tangan) dengan penderita serta menyentuh wajah, mulut, dan hidung oleh tangan yang terpapar virus Corona (Singhal, 2020). Gejala klinis yang muncul akibat terinfeksi virus ini seperti gejala flu biasa (demam, batuk, pilek, nyeri tenggorokan, nyeri otot, nyeri kepala) hingga komplikasi berat (diare dan pneumonia) hingga menyebabkan kematian (Huang dkk, 2020: Chen 2020).

Anak-anak termasuk ke dalam kelompok usia yang sangat rentan terhadap penularan COVID-19 dari lingkungan sekitarnya. Sebagian anak-anak yang terinfeksi COVID-19 seringkali tidak menunjukkan gejala infeksi, (Zimmermann dan Curtis, 2020). Menurut UU Nomor 23 Tahun 2002 tentang perlindungan anak, disebutkan bahwa anak merupakan amanah dan karunia Tuhan YME yang dalam dirinya melekat harkat dan martabat sebagai manusia seutuhnya. Oleh karena itu setiap anak berhak atas keberlangsungan hidup, tumbuh dan berkembang serta berhak atas perlindungan dari kekerasan dan diskriminasi.

Anak yatim piatu adalah mereka yang sudah tidak memiliki orang tua lagi dan keluarga yang memeliharanya. Mereka termasuk anak yang menderita, lemah dan menjadi korban kehilangan kasih sayang orangtua baik di bidang pendidikan ataupun di bidang yang lain (Syaitut, 1991).

Panti asuhan merupakan tempat atau kediaman untuk merawat anak anak yatim piatu (Depdikbud, 1999). Dalam aktivitasnya sehari-hari, setiap anak berinteraksi dengan anak lainnya, dengan berbagai karakteristik yang berbeda serta batasan usia yang berbeda pula. Anak-anak panti asuhan menghabiskan waktu mereka untuk sekolah, belajar, mengaji, dan berbagai kegiatan positif lainnya yang pada masa pandemi ini semuanya dilakukan dari rumah.

Anak-anak panti asuhan dalam kondisi saat ini seyogyanya mendapatkan perhatian khusus tentang cara pencegahan dan penularan Covid-19, hanya saja keterbatasan sumber informasi baik dari 


\section{Jurnal Abdimas Saintika}

Volume 3 Nomor $1 \mid$ https://jurnal.syedzasaintika.ac.id

orang tua, pengasuh, ataupun media lainnya, maka penting dan perlu dilakukan edukasi untuk mengajarkan bagaimana perilaku hidup bersih dan sehat (PHBS). PHBS merupakan sekumpulan perilaku yang dipraktikkan atas dasar kesadaran sebagai hasil pembelajaran yang menjadikan seseorang, keluarga, kelompok atau masyarakat agar mampu menolong dirinya sendiri (mandiri) di bidang kesehatan dan berperan aktif dalam mewujudkan kesehatan masyarakat (Permenkes RI, No. 2269). Perilaku hidup bersih dan sehat (PHBS) untuk pencegahan virus Covid-19 dapat berupa cara mencuci tangan yang baik dan benar dengan memakai sabun minimal 20 detik, cara memakai masker, cara menerapkan etika batuk, dan cara menjaga kebersihan diri, seperti menghindari memegang area yang beresiko tempat penularan covid-19 yaitu mata dan hidung. (Razi, dkk, 2020)

Kegiatan edukasi PHBS sesuai dengan pedoman protokol kesehatan Permenkes RI tahun 2020, yang dilakukan di panti asuhan Ummi al Ikhlas diharapkan dapat memberikan pengetahuan dan keterampilan dalam menerapkan perilaku hidup bersih dan sehat secara mandiri sebagai upaya untuk meminimalisir penularan Covid-19.

\section{METODE}

Berdasarkan pemaparan dan identifikasi masalah mitra, tim pelaksana pengabdian masyarakat, melakukan tahapan dalam penyelesaian masalah tersebut sebagai berikut :

Tujuan Kegiatan ini bertujuan untuk mengidentifikasi perilaku hidup bersih dan sehat dan menambah pengetahuan dan ketrampilan pada anak-anak dan pengasuh panti asuhan untuk meningkatkan kesehatan /imunitas dalam melaksanakan PHBS khususnya protokol kesehatan sebagai upaya untuk meminimalisir penularan virus covid -19 .

Kegiatan

Isi kegiatan a. Perkenalan dan penjelasan tujuan dari kegiatan pengabdian kepada
masyarakat
b. Penjelasan materi tentang penyakit covid 19, resiko dan bahayanya pada
manusia khususnya anak-anak, upaya pencegahan agar tidak tertular
covid-19 dengan perilaku hidup bersih dan sehat serta mentaati protokol
covid- 19. Demontrasi pelaksanaan PHBS dan protokol kesehatan : cara
pemilihan dan pemakaian masker, Etika batuk dan bersin yang benar, cara
mencuci tangan dengan 6 langkah menggunakan sabun dan air mengalir .
c. Tanya jawab dengan audien/anak-anak dan pengasuh panti asuhan.
d. Pendampingan dan Redemonstrasi satu persatu anak-anak dan pengasuh
panti asuhan memakai masker, etika batuk dan bersin yang benar, serta
mencuci tangan yang benar dengan 6 langkah menggunakan sabun dan air
mengalir.
e. Evaluasi Kegiatan Pengabmas bersama anak-anak dan pengasuh panti
asuhan.
f. Pemberian Poster dan leaflet
g. Dokumentasi.

Sasaran

Anak-anak dan Pengasuh Panti Asuhan Ummi Al Ikhlas 


\section{Jurnal Abdimas Saintika}

Strategi Metode kegiatan yang dilakukan :

a. Pendidikan kesehatan/ Ceramah dan Tanya jawab

b. Demonstrasi

c. Pendampingan dan Redemontrasi oleh anak-anak dan pengasuh panti asuhan

\section{HASIL DAN PEMBAHASAN}

Kegiatan pengabdian kepada masyarakat ini telah dilaksanakan sesuai dengan tahapan yang sudah ditetapkan, adapun pelaksanaannya sebagai berikut :

1. Tahap Pembukaan

Sebelum kegiatan dimulai, tim pengabmas melakukan perkenalan diri, yang dipandu oleh moderator, menjelaskan tujuan pelaksanaan kegiatan, melakukan kontrak waktu dengan audien/anak-anak dan pengasuh panti asuhan bahwa kegiatan dilaksanakan selama 60 menit.

2. Tahap pelaksanaan

Sebelum memberikan materi pendidikan kesehatan tentang PHBS , Penyaji mengkaji ulang pengetahuan anak-anak panti asuhan tentang covid 19 dan PHBS, menanyakan pengetahuan anak-anak panti asuhan tentang covid 19, PHBS dan protokol kesehatan. Berdasarkan jawaban dan penjelasan audien/anak-anak panti asuhan banyak yang tidak mengetahui tentang covid-19 dan PHBS serta protokol kesehatan.

Pemberian materi dengan menggunakan power point, laptop dan in focus, serta poster dan leaflet. Materi yang disajikan dengan gambar, tulisan dan video terutama tentang covid-19, PHBS, dan protokol kesehatan. Adapun materi yang diberikan yaitu : pengertian dari covid 19, resiko, tanda dan gejala, dampak covid terhadap kesehatan, pengertian PHBS, pentingnya dilaksanakan PHBS dalam kehidupan sehari-hari serta protokol kesehatan meliputi tentang masker, manfaat menggunakan masker, jenis- jenis masker, cara memakai dan mengganti masker, etika batuk dan bersin yang benar serta cara mencuci tangan dengan 6 langkah menggunakan sabun dan air mengalir .

Pendidikan kesehatan dilakukan dengan metode ceramah dan tanya jawab dengan menjelaskan semua materi, dilakukan demonstrasi cara penggunaan masker, cara batuk dan bersin serta cara mencuci tangan yang benar, dan dilakukan redemonstrasi dengan pendampingan terhadap cara menggunakan masker, batuk dan bersin serta cuci tangan pada seluruh anak-anak panti asuhan Ummi al Ikhlas. Seluruh peserta mengikuti kegiatan dari awal sampai akhir dengan aktif dan antusias yang tinggi oleh semua anak-anak dan pengasuh panti asuhan.

3. Tahap penutupan

Sebelum materi diakhiri moderator memberikan kesempatan kepada peserta untuk bertanya tentang materi yang sudah diberikan. Tim pengabmas menjawab semua pertanyaan yang diberikan peserta. Peserta menanyakan tentang manfaat menggunakan masker, kapan waktu mengganti masker, serta cara mencuci tangan dan kapan saja harus mencuci tangan. Pendidikan kesehatan diakhiri dengan menyimpulkan bersama anak-anak panti asuhan terkait materi yang telah diberikan, serta membuat kesepakatan untuk melaksanakan semua yang telah di informasikan serta foto bersama.

Kegiatan pemberian pendidikan kesehatan ini berlangsung sesuai dengan 


\section{Jurnal Abdimas Saintika}

Volume 3 Nomor $1 \mid$ https://jurnal.syedzasaintika.ac.id

waktu yang disepakati. Pengasuh dan anak anak panti asuhan memiliki sikap yang positif tentang pentingnya PHBS dalam upaya pencegahan penularan covid-19, dan seluruh penghuni panti asuhan Ummi Al- Ikhlas setuju untuk menerapkan PHBS dalam kehidupan sehari hari mereka terutama pada masa pandemi covid-19 ini.

\section{SIMPULAN}

Pengabdian kepada masyarakat tentang tentang Edukasi dan Kampanye Kesehatan Perilaku Hidup Bersih dan Sehat (PHBS) di Era Pandemi Covid-19 bagi Anak Panti Asuhan telah dilaksanakan untuk meningkatkan pengetahuan anak-anak dan pengasuh panti asuhan Ummi al Ikhlas. Kegiatan Pengabdian masyarakat ini telah meningkatkan pengetahuan dan ketrampilan bagi anak-anak dan pengasuh panti asuhan Ummi al Ikhlas serta menumbuhkan kesadaran akan pentingnya Perilaku Hidup Bersih dan Sehat (PHBS) khususnya memakai masker, cara batuk dan bersin, serta cuci tangan, sebagai upaya untuk meminimalisir pencegahan penularan virus Covid-19 dengan melaksanakan protokol kesehatan sesuai dengan pedoman dari Permenkes RI, secara mandiri dan konsisten sehingga dapat mengoptimalkan kesehatan pada anak anak panti asuhan Ummi Al-Ikhlas khususnya pada masa pandemi covid-19 ini.

\section{DAFTAR PUSTAKA}

Chen, Z. M., Fu, J. F., Shu, Q. (2020). Diagnosis and treatment recommendations for pediatric respiratory infection caused by the
2019 novel coronavirus. World Journal of Pediatrics.

Departemen Pendidikan dan Kebudayaan. (1999). Kamus Besar bahasa Indonesia, Edisi Kedua. Jakarta: Balai Pustaka.

Huang C, Wang Y, Li X. (2020). Clicoronavirus in Wuhan, China. Lancet. 395: 497-506.

IDAI. (2020). Panduan Klinis Tata Laksana Covid-19 pada Anak. Idai,33. Retrinical features of patients infected with 2019 novel eved From https://covid19.idionline.org/wpcontent/uploads/2020/08/20.IDAI_pdf

Peraturan Menteri Kesehatan Republik Indonesia Nomor 2269/MENKES/PER/XI/2011 Tentang Pedoman Pembinaan Perilaku Hidup Bersih dan Sehat (PHBS).

Razi F., Yulianty V., Amani, S A., Fauzia J H. (2020). Bunga Rampai COVID-19: Buku Kesehatan Mandiri untuk Sahabat. PD Prokami: Depok.

Singhal, T. (2020). A Review of Coronavirus Disease -2019 (COVID 19). The Indian Journal of Pediatrics, 87(4): $281-286$.

Syaitut, S. M. (1991 ). Metodologi Al Qur'an. CV. Ramadhani: Solo.

WHO. (2020 ). Coronavirus disease (COVID - 19) Situation Report -121. https://www.who.int/docs/default source/coronaviruse/situation reports/20200520 -COVID -19 -sitrep 121.pdf?sfvrsn $=$ c4be2ec6_4, diakses 20 Mei 2020.

Zimmermann, P., dan Curtis,20). Coronavirus Infections in Children Including Covid-19. The Pediatric Infectious Disease Journal. 39(5): 355368. 